Research Articles

\title{
«The Life of Varlaam Khutynsky» As A Source on the History of Childhood
}

\section{«La vida de Varlaam Khutynsky» como fuente sobre la historia de la infancia}

\author{
Alexander Leonidovich Novoselov \\ Applicant, Kazan Federal University, Russia \\ ORCID ID: https://orcid.org/0000-0003-4545-9125 \\ Alla Arkadyevna Salnikova \\ Doctor of History, Professor at the Department of National History, the Institute of International \\ Relations, Kazan Federal University, Russia \\ ORCID ID: https://orcid.org/0000-0002-5498-1401 \\ Received 08-12-20 Revised 09-30-20 \\ Accepted 10-13-20 On line 01-14-21 \\ * Correspondence \\ Citation: \\ Email: alnovo92@mail.ru \\ Alexander Leonidovich Novoselov, Alla Arkadyevna Salnikova. \\ (2021). «The Life of Varlaam Khutynsky» As A Source on the History \\ of Childhood. Propósitos y Representaciones, 9(SPE1), e1226. Doi: \\ http://dx.doi.org/10.20511/pyr2021.v9nSPE1.e1226
}




\section{Summary}

The urgency of this problem is conditioned by the need to expand the research field of such a new, promising and actively developing trend in modern historical science as childhood history. The presence of serious gaps in the study of the history of childhood in Ancient Russia is largely due to the limited data and paucity of information about childhood in the texts of that time. All the more important is the analysis of such a source as "The Life of Varlaam Khutynsky" - a work of ancient Russian hagiographic literature, reflecting the ideas of adults about children and childhood, about the relationship between children and parents, about intergenerational behavioral practices and the ways of their description. The author notes the need for a thorough analysis of hagiographic works that recreate the image of an "ideal" childhood in the Old Russian Orthodox tradition, which is significant for the development of society views and has long been widely demanded in educational and upbringing practices. On the basis of new methodological approaches in the study of hagiography, the article studies the informative potential of "The Life of Varlaam Khutynsky" as a source on the history of childhood. The authors strive to highlight implicit information suitable for reconstructing the daily practices of interaction between children, adolescents, youth and adults. They come to the conclusion that the discourse of the relationship "father - son", constructed in the text of the work, was aimed at strengthening the belief in the holiness of Varlaam within the princely environment. It is proved that the Life of Varlaam Khutynsky had a significant educational potential and was aimed at the younger generation with the aim of not only spreading the veneration of the saint, but also instilling an image of a positive hero corresponding to the ideals of that time.

Keywords: history, childhood, historical anthropology, source study, hagiography, Varlaam Khutynsky, pre-Petrine Russia.

\section{Resumen}

La urgencia de este problema está condicionada por la necesidad de ampliar el campo de investigación de una tendencia tan nueva, prometedora y en desarrollo activo en la ciencia histórica moderna como es la historia de la infancia. La presencia de graves lagunas en el estudio de la historia de la infancia en la antigua Rusia se debe en gran parte a los datos limitados y la escasez de información sobre la infancia en los textos de esa época. Lo más importante es el análisis de una fuente como "La vida de Varlaam Khutynsky", una obra de la literatura hagiográfica rusa antigua, que refleja las ideas de los adultos sobre los niños y la infancia, sobre la relación entre los niños y los padres, sobre las prácticas conductuales intergeneracionales. y las formas de su descripción. El autor señala la necesidad de un análisis exhaustivo de las obras hagiográficas que recrean la imagen de una infancia "ideal" en la antigua tradición ortodoxa rusa, que es importante para el desarrollo de las visiones de la sociedad y ha sido ampliamente demandada durante mucho tiempo en las prácticas educativas y de crianza. Sobre la base de nuevos enfoques metodológicos en el estudio de la hagiografía, el artículo estudia el potencial informativo de "La vida de Varlaam Khutynsky" como fuente sobre la historia de la infancia. Los autores se esfuerzan por resaltar información implícita adecuada para reconstruir las prácticas cotidianas de interacción entre niños, adolescentes, jóvenes y adultos. Llegan a la conclusión de que el discurso de la relación "padre - hijo", construido en el texto de la obra, tenía como objetivo fortalecer la fe en la santidad de Varlaam dentro del entorno principesco. Está comprobado que la Vida de Varlaam Khutynsky tenía un importante potencial educativo y estaba dirigida a la generación más joven con el objetivo no solo de difundir la veneración del santo, sino también de inculcar una imagen de héroe positivo correspondiente a los ideales de esa época. .

Palabras clave: historia, infancia, antropología histórica, estudio de fuentes, hagiografía, Varlaam Khutynsky, Rusia prepetrina. 


\section{Introduction}

The specificity of the source base for Old Russian history is the absence or a relatively small number of sources of personal origin. This greatly complicates the study of the private life of an ancient Russian person. Some of its aspects are reconstructed from separate fragmentary information extracted from a variety of historical sources. For example, V.V. Dolgov, referring to the problem of childhood in Ancient Russia, analyzed the texts of church origin, chronicles, birch bark letters, archaeological and ethnographic materials (Dolgov, 2017). N.L. Pushkareva pointed out the difficulty of reconstructing the history of women, including the history of motherhood in Russia, in the 10th - 15th centuries (Natalia Pushkareva, 2016).

Although these researchers were able to consider some aspects of the history of childhood in pre-Petrine Russia (birth and naming of a child, motherhood, stages of maturation), they identified many problems, but did not highlight them. This concerned, in particular, the problem of the relationship complexity between parents and children. So, V.V. Dolgov drew attention to the fact that even the "Life of Theodosius Pechersky" (XII century) tells about the severity of a future saint upbringing: "a loving mother, seeing that her child does not correspond to generally accepted norms of behavior, "bows down" to her son: she pounds him while she herself will not be exhausted, she puts him in shackles, and locks him in the house" (Dolgov, 2017).

The plot about the parents' "misunderstanding" of the peculiar and atypical behavior of a future saint is a "common place" for all hagiographic literature. This raises a natural question: is this information reliable? An interpretive analysis of the "Life of Varlaam Khutynsky" allows, in our opinion, to answer it in a certain extent.

\section{Methods}

The scientific view of hagiography has recently undergone significant changes. An appeal to the socio-cultural aspects of holiness, the use of interdisciplinary research methods, a comparison of the Western and Eastern models of the "sacred" discourse allowed us to take a fresh look at the lives of saints and the materials of canonization processes (Yatsyk, 2018; Rico \& Monde, Kerry, 2016; James, 2018; Griger et al., 2019; Griger et al.,2018). The range of issues addressed to hagiography expanded significantly and began to include the everyday life of saints and their contemporaries, the anthropology of illness in the Middle Ages, the history of medicine, the specifics of the relationship between the laity and the church, the involvement of holiness in political ideology and the aesthetic canon, even in Russia of modern times (Margaret Ziolkowski, 2014; Karin Hyldal Christensen, 2017). The personality of the protagonist fits into the context of the era, which can also be successfully reconstructed from the hagiographic text.

However, the environment contemporary to the author appears in an idealized form in hagiography. But in order to show the "norm", medieval scribes recorded deviations from the "norm" in one way or another. The latter can provide the real picture of the past. Therefore, methodologically, when analyzing the lives, it is necessary to separate real everyday practices from literary images and clichés by studying the history of the text creation and by its hermeneutic reading and interpretation.

\section{Results and Discussion}

"The Life of Varlaam Khutynsky" is known in several editions. The first, earliest, edition, containing only a short biography of the saint, dates from the end of the 13th century (Klyuchevsky, 1871). This work goes back to the legendary legends about the founder and abbot of the Khutynsky monastery Varlaam (XII century - 1192), who was canonized later (Dmitriev, 1973).

It is customary to date the second edition of the Life to the first quarter of the 15 th century. It describes in much more detail the childhood and adolescence of the future saint. Already at a young age, Varlaam, according to the hagiographer, "тем же и въспитанъ бывъ в добромъ 
наказании, по времени вданъ бысть учитися божественымъ книгамь" (The life of the Monk Varlaam of Khutynsky, the Great Menaion Chetia, collected by the All-Russian Metropolitan Macarius). The people him were amazed at his love of books: “не бо укланятися на некия игры или позоры, но паче на прочитание божественыхъ писаний" (The life of the Monk Varlaam of Khutynsky, the Great Menaion Chetia, collected by the All-Russian Metropolitan Macarius). The adolescent's insistence was expressed not only in reading the books of Holy Scripture, but also in abstaining from food: «начатъ же въздръжатися и весма сладкыхъ брашенъ отнюдъ не ясти» (The life of the Monk Varlaam of Khutynsky, the Great Menaion Chetia, collected by the AllRussian Metropolitan Macarius).

This part of the Life is not very informative for the history of childhood, because it consists entirely of literary topos, which described the biography of the saints. The only thing that you can pay attention to is the opposition that the author uses. Love for the books by the young Varlaam in the Life is contrasted with sympathy for "games" and "shame" (that is, "spectacles"). Recording the "canonical" ideal quality of a saint in youth - love of books, the hagiographer also captures a real picture of the Old Russian youth interests - games and love of spectacles. The condemnation of the holidays was typical of the Old Russian scribes. Most clearly, amusements are condemned in Domostroi: "всякое скаредие творя (...) песни бесовские, плясание, скакание, гудение, бубны, трубы, сопели и медведи и птици и собаки ловчи творящее и коньские уристание всяко бесовское угодие и всяко бесзчиние и безстрашие к сему же чарование" (Domostroy,2007).

The description of the relationship between young Varlaam and his parents, who do not understand the future saint, is completely subordinate to the canons. The appearance of this hagiographic topos in the second edition of the "Life of Varlaam Khutynsky" is associated with the influence of the "Life of Sergius of Radonezh" (early 15th century) (Dmitriev, 1973).

The second edition is added with the lifetime and posthumous miracles of the saint associated with children and youth: the prediction of the birth of a son to the Novgorod prince Yaroslav Vladimirovich (1190), the resurrection of the son of a farmer (1190-ies) and the healing of the young prince Konstantin Dmitrievich (between 1408 - 1412). Apparently, the last miracle was the reason for the creation of the second edition of "The Life of Varlaam Khutynsky".

Let's consider the "wonder about the resurrection of the dead." A certain farmer's son fell ill in the story. "Having faith" to the Saint Varlaam of Khutynsky, the farmer decided to go with him to the saint. However, the lad died on the way. Varlaam commanded the farmer to leave his son in his room, and to prepare the burial himself. Through the prayer of the saint, the youth was resurrected (The life of the Monk Varlaam of Khutynsky, the Great Menaion Chetia, collected by the All-Russian Metropolitan Macarius).

There is no doubt that the author in this episode is interested in a deep religious meaning, which is revealed through the reference to the Gospel. The miracle of the youth resurrection by Varlaam repeats symbolically the Gospel miracle of the widow's son resurrection in Nain (Luke 7: 11-17). The saint is likened to Jesus Christ, the farmer and his "only begotten" son - the only widow's son who died and rose again.

The Miracle of the Resurrection of the Dead shows what an "ideal" father should be. According to Christian dogma, miraculous healings and resurrection can occur only under one condition - faith. The hagiographer repeatedly emphasizes that the farmer "had great faith" in Varlaam. This faith gave him the strength to go with his son to the saint.

A similar plot is present in the Life of St. Sergius of Radonezh. However, the theme of children's healing does not receive the same development in it as in the "Life of Varlaam of Khutynsky": of the six miracles of Sergius in his lifetime, only one appears as a youth, and there are no adolescents or children in his numerous posthumous miracles (Life of Sergius of Radonezh, 1999). In " The Life of Varlaam Khutynsky" children and young men appear in seven miracles out of 13 , and in terms of the text volume, these seven episodes are much larger than the rest. 
Presumably in the 40-ies of the XV century famous hagiographer Pachomius Logofet creates a new edition of the Life of Varlaam (Dmitriev, 1973). This edition contains a description of new miracles associated with children and adolescents - about the healing of the dumb and about the healing of the raging.

In the miracle of the mute, the thing is about the son of "a certain merchant Anthony", who "happened to be numb." Antony was in great despair. He went to the monastery, to the relics of St. Varlaam. "И тамо ему бывшу и с сыномъ своимъ в манастыре и у раки святого отца доволно сь слезами молитвовавшу." After Anthony's prayer, his son spoke (The life of the Monk Varlaam of Khutynsky, the Great Menaion Chetia, collected by the All-Russian Metropolitan Macarius). Unlike the case with the farmer, the hagiographer does not emphasize Anthony's faith in Varlaam here, but retains the typical course of the plot - to heal the ailment, the father and his son set off on the path to the saint and pray. Let us note that the sons are absolutely inactive in these miracles. The father is in the center of the narrative, in addition to the saint. The figure of a father, who has faith in the monk, in the miracles of "The Life of Varlaam of Khutynsky" is the most important didactic example.

Another example is the miracle of the raging one. Ivan, the son of "a certain priest," was possessed by a demon. He bit off a finger on his right hand. Ivan's mother realized that no amount of healing would help, and decided to take her son to the monastery, to the relics of St. Varlaam. In the monastery, she performed a prayer, and Ivan's rage weakened. But after returning home, Ivan became possessed by demons again. He was brought to the monastery again. Only after "many days" he was healed. Ivan accepted the covenant: every year to come to the monastery and perform a prayer service (The life of the Monk Varlaam of Khutynsky, the Great Menaion Chetia, collected by the All-Russian Metropolitan Macarius).

In this case, the main plot is preserved - the healing of the son takes place through the prayer of the parent (mother) to the Saint Varlaam. However, attention here is already shifted to his son: his name is called and in general Ivan is the main character - he talks with demons, inflicts damage on himself, and praises God. Thus, if in previous miracles the author turned to readersparents, showing them what an "ideal", "faithful" father or mother should be, then in a miracle about a raging person he is more likely to address youth.

The same problem is solved by another miracle about the raging one. The main character here is also a young man possessed by a devil: he "лаяше бо яко песь и рыкаше яко скоть и многы и иныа гласы неподобны испущаa." As soon as he is brought to the monastery bound, he is healed immediately (The life of the Monk Varlaam of Khutynsky, the Great Menaion Chetia, collected by the All-Russian Metropolitan Macarius). The author proves once again that the Khutynsky monastery is a place where a person of any age receives protection.

The theme of "fathers and children" is presented in the miracles discussed above, which, in our opinion, is the key one in "The Life of Varlaam of Khutynsky". The main goal of the work is also realized through it - the assertion of the saint's holiness not only among ordinary people, but also among the Novgorod and Moscow princes. Three miracles are dedicated to this goal: about the prophecy of the saint, about Prince Constantine and about Gregory Tumgan. If the first two miracles appeared in the "Life of Varlaam Khutynsky" in the second edition, the last one was completed by Pachomius Logofet in the 70-ies of XV century.

The miracle about the prophecy of the saint tells how Varlaam predicted the birth of a son to the prince of Novgorod Yaroslav Vladimirovich in 1190. This miracle is intended to explain the origin of Yaroslav's "great faith" in the saint, and thereby to affirm the holiness of Varlaam by a Novgorod prince. Yaroslav brought his son to be baptized to the Khutynsky abbot (The life of the Monk Varlaam of Khutynsky, the Great Menaion Chetia, collected by the All-Russian Metropolitan Macarius). Varlaam becomes the spiritual father to the son of Prince Yaroslav because Yaroslav came to the holy "begging of blessing by his own will." According to Yaroslav's faith, the miracle of the prophecy happened. 
Local veneration for Varlaam begins soon after his death. Over time, Varlaam Khutynsky became the main Novgorod saint. In the 15th century Novgorod clergy seeks to spread his cult not only in the Novgorod land, but also beyond its borders. This is one of the main reasons for the creation of the second edition of the "Life of Varlaam Khutynsky" at the beginning of the 15th century. The reason was the miracle of Prince Konstantin Dmitrievich, who, being the Prince of Novgorod at the behest of Vasily I (1408-1412), was healed by the relics of Varlaam from a serious illness (The life of the Monk Varlaam of Khutynsky, the Great Menaion Chetia, collected by the All-Russian Metropolitan Macarius). According to the annals, this event took place in 1407 (Complete collection of Russian chronicles, 2001). Konstantin was 17 years old at that time. The miracle of the healing of the prince from a Moscow house by the Novgorod saints was a symbolic declaration of the holiness of Varlaam Khutynsky not only for Novgorodians, but also for all Russian lands.

The beginning of the all-Russian veneration of Varlaam Khutynsky comes from the miracle of 1460 about Grigory Tumgan (Novoselov \& Kapustina, 2019). The story of the miraculous resurrection of Basil II in bed contains valuable information both about the perception of the disease and its causes and helps to understand the people of that time. The text describes in detail the course of Gregory's serious illness, shows his feelings, changing from deep despair and a premonition of death to great joy after a miraculous healing (The life of the Monk Varlaam of Khutynsky, the Great Menaion Chetia, collected by the All-Russian Metropolitan Macarius).

Pakhomy Logofet in his life story about Tumgan relied on the original text created by Rodion Kozhukh and preserved in the Sofia second chronicle. There is an interesting detail in the chronicle version of the miracle with Tumgan. After death, the soul of Gregory goes to the afterlife judgment. The demons present there scrolls on which "all the evil thoughts" of Gregory are written, "еже здеяхь от юности моеа." Moreover, the sins of which the youth repented are "blotted out on the scrolls." At the same time, the guardian angel of Gregory presents a scroll with his good deeds, but "there is a small text in it." However, the small virtue of Gregory outweighs the sins, since he took the sacrament before his death (Complete collection of Russian chronicles, 2001). Young people, the author implies, are more prone to sinful life. However, Gregory's faith helped him and Nikola and Varlaam Khutynsky appeared to save his soul.

Kozhukh draws attention to the importance of caring for the son in relation to his parents. Once in paradise, Gregory wants to stay there, but Varlaam encourages him to return to his parents, so as "not to soften them" and "to comfort crying and sobbing" (Complete collection of Russian chronicles, 2001).

\section{Conclusions}

"The Life of Varlaam Khutynsky" was created over several centuries (XII-XV centuries). During this time, the text of the work has undergone changes and additions. The authors of the Life were originally Novgorod monks, who accumulated the traditions and wonders of Varlaam. In the XV century "The Life of Varlaam Khutynsky" was written by the master of the hagiographic genre of that time - Pakhomy Logofet. In the 70-ies of the XV century the life of the monk was supplemented by a lengthy miracle about Grigory Tumgan, created by the metropolitan clerk, the talented writer Rodion Kozhukh.

The purpose of "The Life of Varlaam of Khutynsky" creation, like other works of the hagiographic genre, is to assert holiness, to promote the spread of the saint veneration. "The Life of Varlaam Khutynsky" is intended for the widest strata of the population. But, based on the subject matter of the work, we can assume that one of the main addressees of it were parents and children. In the miracles of Varlaam, the image of a "correct" parent is developed, believing in the saint's holiness. For the sake of the faith of such parents, the Novgorod saint heals their children. On the other hand, the work also addresses youth, showing what a son should be like: humble, respectful of parents, ready for repentance, visiting a monastery and paying homage to the saint. the authors of the life point to the causes of illness for the young, - a sinful life that takes place in 
amusements, demonic possession. And only in the Khutynsky monastery children and youth will be able to find a protector from the temptations and devilish intrigues through the Saint Barlaam.

\section{Conclusion}

Behind the abundance of rhetorical tricks, direct and indirect quotations from the Holy Texts or other hagiographic works, it is extremely difficult to discern what the real situation of a child, adolescent or youth was in ancient Russian society according to the "Life of Varlaam Khutynsky". This information is hidden in the details and contrasts, to which the author resorts to show the positive characters. Thus, the most detailed description of the course of Grigory Tumgan's illness suggests a clear departure from literary clichés and thereby gives a real picture of the illness that the young man suffered in the middle of the 15th century. In the case of Varlaam, his childhood and adolescence appears to be a model in contrast to the real picture of the idleness and rough fun of his peers.

Clearly defined political goals are achieved through the image of a son (a young man or a servant) in the Life. Miracles with the son of the Novgorod prince Yaroslav, with the son of the Moscow prince Dmitry Donskoy Konstantin Dmitrievich, with the servant of Vasily II are called to strengthen the glory of Varlaam in the princely environment.

On the whole, the "Life of Varlaam Khutynsky" had a great educational potential and was oriented not only to spread the veneration of the monk, but also to implant the image of a positive hero corresponding to the ideals of that time.

\section{Acknowledgements}

The work is performed according to the Russian Government Program of Competitive Growth of Kazan Federal University.

\section{References}

(2001). Complete collection of Russian chronicles, 6(2), Moscow, The languages of Russian culture, par. 416.

Dmitriev, L.A. (1973). Lives of the Russian North as Literary Monuments of the 13th-17th centuries. Evolution of the genre of legendary biographical legends, Leningrad, Nauka, $304 \mathrm{p}$.

Dolgov, V.V. (2017). Life and customs of Ancient Russia. Worlds of everyday life in XI-XIII centuries, St. Petersburg, Publishing house of Oleg Abyshko, 592 p.

Domostroy, St. Petersburg, Nauka, 2007. 425 p.

Griger, M.V., Vostrikov, I.V., \& Dusaeva, E.M. (2019). Creating a memory of a saint: Francis of Assisi in Italian Monumental Propaganda of the 19th-21st centuries, Humanities \& Social Sciences Reviews, 7(5), 663-666.

Griger, M.V., Dusaeva, E.M., \& Khanbekova, N.I. (2018). San Francis of Assisi in Italian cultural memory (19th - 20th century), Revista Publicando, 5(16), 717-724.

James, T. (2018). Palmer, Early Medieval Hagiography, Leeds, Arc, 122 p.

Karin Hyldal Christensen, (2017). The Making of the New Martyrs of Russia: Soviet Repression in Orthodox Memory, London, Routledge, 234 p.

Klyuchevsky, V.O. (1871). Old Russian Lives of Saints as a Historical Source, Moscow. The Edition by K. Soldatenkov, 479 p.

Life of Sergius of Radonezh, (1999). Library of Literature of Ancient Rus, vol. 6, St. Petersburg, Nauka, 254-412.

Margaret Ziolkowski, (2014). Hagiography and Modern Russian Literature, Princeton, N.J., Princeton University Press, $282 \mathrm{p}$.

Natalia Pushkareva, (2016). Eve Levin, Women in Russian History: From Tenth to the Twentieth Century, New York, Routledge, 300 p.

Novoselov, A.L., \& Kapustina, E.V. (2019). The miracle of the dead lad in the Sofia Second Chronicle. Opción, Año 35, Especial, 22, 859-872. 
Rico, G., Monde, Kerry, P.C. (2016). San Chirico, Rachel J. Smith, Hagiography and Religious Truth: Case Study in the Abrahamic and Dharmic Traditions, New York, Bloomsbury, 288 p.

The life of the Monk Varlaam of Khutynsky, the Great Menaion Chetia, collected by the AllRussian Metropolitan Macarius, November, issue 7, days 1-12, St. Petersburg, 1897. par. 884.

Yatsyk, S.A. (ed.). (2018). The Europe of Saints. Social, political and cultural aspects of holiness in the Middle Ages, St. Petersburg, Aletheia, 324 p. 